\title{
Questes
}

\section{Au nom du père et du fils. La transmission didactique dans Le Chastoiement d'un pere a son fils, recueil édifiant du XIII ${ }^{\mathrm{e}}$ siècle}

\section{Caroline Mounier}

\section{(2) OpenEdition}

\section{Journals}

\section{Édition électronique}

URL : http://journals.openedition.org/questes/592

DOI : 10.4000/questes.592

ISSN : 2109-9472

\section{Éditeur}

Les Amis de Questes

\section{Édition imprimée}

Date de publication : 15 mars 2007

Pagination : 36-48

ISSN : 2102-7188

\section{Référence électronique}

Caroline Mounier, «Au nom du père et du fils. La transmission didactique dans Le Chastoiement d'un pere a son fils, recueil édifiant du XIII e siècle », Questes [En ligne], 11 | 2007, mis en ligne le 01 janvier 2014, consulté le 30 avril 2019. URL : http://journals.openedition.org/questes/592 ; DOI : 10.4000/ questes.592

Ce document a été généré automatiquement le 30 avril 2019.

(C) Association des amis de "Questes » 


\title{
Au nom du père et du fils. La transmission didactique dans Le Chastoiement d'un pere a son fils, recueil édifiant du XIII ${ }^{e}$ siècle
}

\author{
Caroline Mounier
}

\section{NOTE DE L'ÉDITEUR}

Cet article n'a pas encore fait l'objet d'une autorisation de publication.

INDEX

Keywords : transmission, son, father, anecdote, didactic

Mots-clés : fils, père, filiation, exemplum, didactique 